\title{
Genotype $\times$ environment interaction and grain yield stability in Chinese hybrid rice
}

\author{
Jiban Shrestha ${ }^{1}$, Ujjawal Kumar Singh Kushwaha ${ }^{1}$, Bidhya Maharjan ${ }^{1}$, Sushil Raj Subedi ${ }^{2}$, \\ Manoj Kandel ${ }^{3}$, Amrit Prasad Poudel ${ }^{4}$ and Rajendra Prasad Yadav ${ }^{5}$ \\ ${ }^{I}$ Nepal Agricultural Research Council, Agriculture Botany Division, Khumaltar, Lalitpur, Nepal \\ ${ }^{2}$ National Rice Research Program, Hardinath, Dhanusha, Nepal \\ ${ }^{3}$ Hill Crops Research Program, Kabre, Dolakha, Nepal \\ ${ }^{4}$ Regional Agricultural Research Station, Lumle, Kaski, Nepal \\ ${ }^{5}$ Regional Agricultural Research Station, Parwanipur, Bara, Nepal \\ Correspondence: jibshrestha@gmail.com, (iD https://orcid.org/0000-0002-3755-8812
}

Received: $12^{\text {th }}$ October 2019, Revised: $19^{\text {th }}$ May 2020, Accepted: $15^{\text {th }}$ June 2020

\begin{abstract}
Multi-environment testing helps to identify stable genotypes. The objective of this study was to evaluate Chinese hybrid rice varieties for their grain yield and yield stability at different environments. The multilocation rice evaluation trials were conducted during summer seasons of 2017 and 2018 at five different environments, namely, Hardinath (Dhanusha), Kabre (Dolakha), Parwanipur (Bara), Khumaltar (Lalitpur) and Dhakaltar (Tanahun) in Nepal. Four hybrid rice varieties namely LPNBR1618, LPNBR1615, LPNBR1628 and LPNBR1632 (Standard check variety) were evaluated in a randomized complete block design with four replications in each location. The results indicated a significant $(\mathrm{p}<0.05)$ variation in grain yield among the genotypes at Hardinath, Khumaltar, and Kabre whereas they were non-significant for grain yield at Dhakaltar and Parwanipur. The combined analysis of variance indicated significant $(p<0.05)$ effects of environment and genotype $\times$ environment $(G \times E)$ interactions on grain yield. The pooled data over locations and years showed that LPNBR1632 produced the highest grain yield ( 7.5 tons/ ha) followed by LPNBR 1618 (6.3 tons/ ha) in terai region (Hardinath and Parwanipur). Similarly, LPNBR1618 gave the highest grain yield (10.3 tons/ ha) followed by LPNBR1615 (9.5 tons/ ha) in mid hills region (Kabre, Khumaltar and Lumle). The genotypes LPNBR1615 ( $b=1.13)$, LPNBR1618 $(b=1.19)$ and LPNBR1628 $(b=1.15)$ had more than unity regression indicating the genotype's suitability towards favorable environments. GGE biplot showed genotype LPNBR1615 was stable genotype among all genotypes. This study suggests that LPNBR 1615 can be grown for higher grain yield production in terai and mid hills of Nepal.
\end{abstract}

Keywords: Multi-environments, genotype stability, rice hybrid varieties.

\section{Introduction}

Rice (Oryza sativa L.) is one of the most important cereal crops which serves as the primary source of staple food for more than half of the global population (Ricepedia 
2020, USDA 2020). Approximately, 90\% of the world's rice is grown in the Asian continent and it constitutes a staple food for 2.7 billion people worldwide (Paranthaman et al. 2009). Rice is the number one staple food crop in Nepal and contributed significantly to livelihood of majority of people and to national economy. The total area, production and productivity of rice is 1.49 million ha, 5.61 million tons and 3.76 tons/ ha in Nepal (CBS 2018). In Nepal, rice self-sufficiency ratio is below 100 , which means that the domestic rice production is not sufficient to meet the domestic consumption (Tripathi et al. 2019). Nepal Agricultural Research Council (NARC) has been playing a significant role to improve the rice productivity in the country. The current production is not sufficient to meet the demand of growing population and ensure food security in the country.

Chinese hybrid rice varieties have increased yields, productivity, and profitability (IRRI 2019). Hybrid rice cultivation in China and many other Asian countries like Bangladesh, India, Philippines, and Vietnam showed a 20-30\% yield advantage over inbred rice varieties (Virmani 2003). The evaluation of hybrid rice genotypes under different environments is one of the important tasks of rice breeding program. The genotypes should be screened in multi-environments representing various ecological domains to identify and select for the most stable and adaptable genotypes over a wide range of environment. The grain yield depends on genotype, environment and management practices and their interaction with each other (Messina et al. 2009). The level of performance of any character is a result of the genotype $(G)$ of the cultivar, the environment in which it is grown (E), and the interaction between $\mathrm{G}$ and $\mathrm{E}(\mathrm{G} \times \mathrm{E})$. The interaction between these two explanatory variables gives an insight for identifying genotypes suitable for specific environments. The environmental effect is typically a large contributor to total variation (Blanche et al. 2009). The grain yield of hybrid rice varieties varied with soil and climate factors (Huang et al. 2017). Large contribution of the environment component to grain production in rice has been similarly reported by many works (Wade et al. 1999, Samonte et al. 2005, Acuna et al. 2008).

Phenotypic expression of any variety is mainly governed by the interactions between genotype and environment, and cultivars thus show phenotypic variations in response to the changes in the environment. If the cultivar shows less variation as to changes in environment, then it becomes stable and is preferred by breeders in variety selection process. Therefore, the stability analysis is required to characterize the performance of varieties in different environments, and to help plant breeders in selecting desirable varieties. An information on $\mathrm{G} \times \mathrm{E}$ interaction leads to the successful evaluation of a stable genotype, which could be used for cultivation. The evaluation of genotypes for stability of performance under varying environmental conditions for yield has become an essential part of any breeding programme. Therefore, the objective of the present study was to identify high yielding and stable Chinese hybrid rice genotypes. 


\section{Material and Methods}

\subsection{Plant material and experimental sites}

The Chinese hybrid rice genotypes namely LPNBR 1615, LPNBR 1618, LPNBR 1628 and LPNBR 1632 were obtained from Yuan Longping Agriculture Hi Tech Co. Ltd, Changsha, Hunan, PR, China. LPNBR1632 was used as check variety because it has been already adapted by farmers in their field. These experiments were conducted at Khumaltar (Lalitpur), Hardinath (Dhanusha), Kabre (Dolakha), Parwanipur (Bara) and Dhakaltar (Tanahun), the outreach (OR) site of Lumle (Kaski) of Nepal. The descriptions of experimental locations are given in Table 1. Similarly, the descriptions of climate data of the experimental locations were given in Table $2 \mathrm{a}$ and Table $2 \mathrm{~b}$.

Table 1: Details of experimental locations.

\begin{tabular}{llcl}
\hline $\begin{array}{l}\text { Experimental } \\
\text { location }\end{array}$ & Geographical details & Soil & References \\
\hline $\begin{array}{l}\text { Kabre } \\
\text { (Dolakha) }\end{array}$ & $\begin{array}{l}86^{\circ} 9^{\prime} \mathrm{E}, 27^{\circ} 38^{\prime} \mathrm{N} \\
1740 \mathrm{~m} \text { altitude }\end{array}$ & $\begin{array}{c}\text { Sandy loam soil with pH } \\
\text { from 4.5 to 6.2. i.e. slightly } \\
\text { acidic }\end{array}$ & NARC 2018 b \\
$\begin{array}{l}\text { Hardinath } \\
\text { (Dhanusha) }\end{array}$ & $\begin{array}{l}85^{\circ} 57^{\prime} \mathrm{E}, 26^{\circ} 47^{\prime} \mathrm{N} \\
93 \mathrm{~m} \text { altitude }\end{array}$ & $\begin{array}{c}\text { Silty clay to sandy loam } \\
\text { soil with pH 6.3 }\end{array}$ & NARC 2018 a \\
$\begin{array}{l}\text { Khumaltar } \\
\text { (Lalitpur) }\end{array}$ & $\begin{array}{l}85^{\circ} 2^{\prime} \mathrm{E}, 27^{\circ} 4^{\prime} \mathrm{N} \\
1350 \mathrm{~m} \text { altitude }\end{array}$ & Clayey loam soil & NARC 2018 c \\
$\begin{array}{l}\text { Dhakaltar } \\
\text { (Lumle, Kaski) }\end{array}$ & $\begin{array}{l}84^{\circ} 26^{\prime} 01.3^{\prime \prime} \mathrm{E}, \\
28^{\circ} 03^{\prime} 33.7^{\prime \prime} \mathrm{N}\end{array}$ & $\begin{array}{c}\text { Loam soil with pH 5.6, i.e. } \\
\text { moderately acidic }\end{array}$ & NARC 2018 d \\
$\begin{array}{l}\text { Parwanipur } \\
\text { (Bara) }\end{array}$ & $27^{\circ} 21^{\prime} \mathrm{N}$ and $84^{\circ} 53^{\prime} \mathrm{E}$ & $\begin{array}{c}\text { Silt loam soil with pH 5.67, } \\
\text { i.e., moderately acidic }\end{array}$ & $\begin{array}{l}\text { Bhurer 2013, } \\
\text { Khadka } \text { et al. } 2018\end{array}$ \\
\hline
\end{tabular}

\subsection{Experimental design and agronomic management practices}

The experiment was carried out during two consecutive summer or rainy seasons of 2017 and 2018 in a randomized complete block design (RCBD) with four replications. The plot size was maintained at $6 \mathrm{~m}^{2}$. The planting geometry was maintained as $20 \mathrm{~cm}$ $\times 15 \mathrm{~cm}$. Fertilizer and farmyard manure $(F Y M)$ were applied at the rate of 120: 60: $40 \mathrm{NPK} \mathrm{kg} / \mathrm{ha}$ and 10 tons/ ha respectively as per the recommendation of National Rice Research Program (NRRP), Hardinath, Dhanusha, Nepal. Full dose of $\mathrm{P}_{2} \mathrm{O}_{5}$ and $\mathrm{K}_{2} \mathrm{O}$ and half dose of $\mathrm{N}$ were applied as basal dose and remaining $50 \%$ nitrogenous fertilizer was further split into two parts. The first part was applied at the tillering stage and the second part was applied at the booting stage. The genotypes were evaluated based on measurement of grain yield. The grain yield was calculated using the formula adopted by Paudel (1995). 


$$
\text { Grain yield }\left(\frac{\mathrm{kg}}{\mathrm{ha}}\right) \text { at } 12 \% \text { moisture }=\frac{(100-\mathrm{M}) \times \text { Plot yield }(\mathrm{kg}) \times 10000 \mathrm{~m}^{2}}{(100-12) \times \text { Net plot area, } \mathrm{m}^{2}}
$$

where, $\mathrm{M}$ is the grain moisture content in percentage.

Table 2a: Climate data of the experimental locations (Khumaltar, Kabre and Hardinath).

\begin{tabular}{llllllllll}
\hline & \multicolumn{3}{c}{ Khumaltar } & \multicolumn{3}{c}{ Kabre } & \multicolumn{3}{c}{ Hardinath } \\
\cline { 2 - 10 } Month & $\begin{array}{l}\text { Max. } \\
\text { Temp. }\end{array}$ & $\begin{array}{l}\text { Min. } \\
\text { Temp. } \\
\left({ }^{\circ} \mathrm{C}\right)\end{array}$ & $\begin{array}{l}\text { Rainfall } \\
(\mathrm{mm})\end{array}$ & $\begin{array}{l}\text { Max. } \\
\text { Temp. } \\
\left({ }^{\circ} \mathrm{C}\right)\end{array}$ & $\begin{array}{l}\text { Min. } \\
\text { Temp. } \\
\left({ }^{\circ} \mathrm{C}\right)\end{array}$ & $\begin{array}{l}\text { Rainfall } \\
(\mathrm{mm})\end{array}$ & $\begin{array}{l}\text { Max. } \\
\text { Temp. } \\
\left({ }^{\circ} \mathrm{C}\right)\end{array}$ & $\begin{array}{l}\text { Min. } \\
\text { Temp. } \\
\left({ }^{\circ} \mathrm{C}\right)\end{array}$ & $\begin{array}{l}\text { Rainfall } \\
(\mathrm{mm})\end{array}$ \\
\hline Jul-17 & 28.2 & 20.6 & 216.2 & 25 & 19 & 497 & 32.87 & 26.61 & 331.7 \\
August & 28.2 & 20.5 & 266.1 & 27 & 18 & 478.1 & 32.23 & 26.71 & 364.2 \\
September & 28.7 & 19.6 & 103.1 & 27.5 & 17.5 & 243.2 & 33.19 & 25.97 & 176.9 \\
October & 27.6 & 15.6 & 1.1 & 27 & 12.3 & 58 & 31.78 & 23.19 & 33.5 \\
November & 23.5 & 8 & 0.3 & 24.5 & 9 & 0 & 29.33 & 15.32 & 0 \\
December & 21 & 4.4 & 0 & 21.5 & 7.8 & 0 & 24.99 & 12.01 & 0 \\
Jan-18 & 18.5 & 2.1 & 7 & 19.3 & 5.5 & 6.2 & 17.12 & 8.89 & 1.4 \\
February & 21.2 & 5.8 & 2.7 & 24.3 & 7 & 3 & 25.25 & 11.86 & 0.3 \\
March & 25.1 & 9.1 & 24.5 & 24.5 & 8.3 & 32 & 31.39 & 16.15 & 1.5 \\
April & 26 & 12.9 & 86.9 & 26.5 & 12.5 & 73.6 & 33.27 & 20.59 & 150.1 \\
May & 27 & 16.5 & 60.2 & 28.5 & 13.3 & 180.3 & 33.95 & 24.37 & 69.7 \\
June & 29.1 & 20.3 & 127.5 & 28.8 & 17 & 181.2 & 34.95 & 25.96 & 227.7 \\
\hline Source: NARC
\end{tabular}

Source: NARC (2018 a, 2018 b, 2018 c, 2018 d, 2018 e)

Table 2b: Climate data of the experimental locations (Parwanipur and Dhakaltar).

\begin{tabular}{lllllll}
\hline \multirow{3}{*}{ Months } & \multicolumn{3}{c}{ Parwanipur } & \multicolumn{3}{c}{ Dhakaltar } \\
\cline { 2 - 7 } & $\begin{array}{l}\text { Max. } \\
\text { Temp. } \\
\left({ }^{\circ} \mathrm{C}\right)\end{array}$ & $\begin{array}{l}\text { Min. } \\
\text { Temp. } \\
\left({ }^{\circ} \mathrm{C}\right)\end{array}$ & $\begin{array}{l}\text { Rainfall } \\
(\mathrm{mm})\end{array}$ & $\begin{array}{l}\text { Max. } \\
\text { Temp. } \\
\left({ }^{\circ} \mathrm{C}\right)\end{array}$ & $\begin{array}{l}\text { Min. } \\
\text { Temp. } \\
\left({ }^{\circ} \mathrm{C}\right)\end{array}$ & $\begin{array}{l}\text { Rainfall } \\
(\mathrm{mm})\end{array}$ \\
\hline Jul-17 & 32.97 & 26.25 & 272.2 & 24.76 & 17.47 & 1702.7 \\
August & 32.38 & 26.42 & 630.9 & 24.1 & 17.9 & 1100.4 \\
September & 33.61 & 25.55 & 188.1 & 24.27 & 19.1 & 578.6 \\
October & 32.62 & 22.69 & 4.4 & 22.94 & 17.37 & 343.7 \\
November & 29.32 & 14.61 & 0 & 18.86 & 9.18 & 2.5 \\
December & 23.99 & 11.33 & 0 & 17.09 & 7.03 & 30.9 \\
Jan-18 & 15.6 & 8.28 & 0 & 14.21 & 4.4 & 4.5 \\
February & 25.33 & 11.12 & 0 & 17.35 & 7.28 & 30 \\
March & 32.2 & 16.07 & 5 & 20.68 & 10.13 & 82.3 \\
April & 34.12 & 21.78 & 61.6 & 21.11 & 11.75 & 155.6 \\
May & 33.62 & 23.88 & 133.2 & 22.35 & 14.29 & 243.5 \\
June & 34.82 & 26.06 & 283 & 24.49 & 17.05 & 616.6 \\
\hline Source: NARC & 2018 & $20186,2018 c, 2018$ & $2018 \mathrm{c})$ & & & \\
\hline
\end{tabular}

Source: NARC (2018 a, 2018 b, 2018 c, 2018 d, 2018 e) 


\subsection{Statistical analysis}

Data from each location were subjected to Analysis of Variance (ANOVA) individually to explore differences among entries for grain yield trait and pooled across locations to determine $\mathrm{G} \times \mathrm{E}$ interaction. The significant $\mathrm{G} \times \mathrm{E}$ were used for stability analysis of Eberhart and Russell model (1966). A genotype with unit regression coefficient $(\mathrm{bi}=1)$ and deviation not significantly different from zero $\left(\mathrm{S}^{2} \mathrm{di}=0\right)$ was taken to be a stable genotype with unit response.

As described by Eberhart and Russell (1966), the behavior of the cultivars was assessed by the model $Y_{i j}=m+b_{i} I_{j}+d_{i j}+\bar{\varepsilon}_{i j}$ where $Y_{i j}=$ observation of the $i^{\text {th }}(i=1$, $2, \ldots, g)$ cultivar in the $j^{\text {th }}(j=1,2, \ldots n)$ environment, $m=$ general mean, $b_{i}=$ regression coefficient, $\mathrm{I}_{\mathrm{j}}=$ environmental index obtained by the difference among the means of each environment and the general mean $\left(\sum_{j=1}^{n} I_{j}=0\right), \delta_{i j}=$ the regression deviation of the $i^{\text {th }}$ cultivar in the $j^{\text {th }}$ environment and $e_{i j}=$ residual error. $d_{i j}=j$ - interaction of $i^{\text {th }}$ genotype in the $\mathrm{j}^{\text {th }}$ environment.

The mean comparisons among genotype means were estimated by the least significant difference (LSD) test at 5\% levels of significance (Gomez and Gomez 1984). The ANOVA was performed using RCBD to derive variance components using GenStat statistical package (12 $2^{\text {th }}$ edition) (Payne et al. 2009). The stability analysis was done using GEAR software Version 4.1 (Pacheco et al. 2015).

\section{Results and Discussion}

\subsection{Grain yield at various environments}

The Chinese hybrid rice genotypes varied significantly $(\mathrm{p}<0.05)$ for their grain yield at Hardinath, Kabre and Khumaltar. They were non-significant for grain yield in Dhakaltar and Parwanipur (Table 3, Table 4 and Table 5). The locations differ greatly in altitude, temperature and rainfall that affects performance. The genotypes varied significantly $(\mathrm{p}<0.05)$ for their grain yield over the locations and years. At Khumaltar condition, genotypes LPNBR1628 (12.77 tons/ ha) and LPNBR1615 (11.94 tons/ ha) produced significantly higher grain yield in contrast to the check variety LPNBR1632 (7.66 tons/ ha) (Table 5). At Kabre condition, genotype LPNBR1618 produced the maximum grain yield of 12.70 tons/ ha followed by LPNBR1615 (10.20 tons/ ha) and LPNBR1628 (9.20 tons/ ha) (Table 5). The genotypes LPNBR1632 (7.46 tons/ ha), and PNBR1618 (5.70 tons/ ha) produced the maximum grain yield at Hardinath condition. At Dhakaltar condition, LPNBR1618 (6.62 tons/ ha) and LPNBR1615 (6.47 tons/ ha) produced the maximum grain yield. Similarly, LPNBR1632 produced the highest grain yield (7.60 tons/ ha) followed by LPNBR1615 (7.07 tons/ ha) and LPNBR 1618 (6.96 tons/ ha) at Parwanipur condition in 2017 and 2018 (Table 5). The pooled data over locations and years showed that LPNBR1632 produced the highest grain yield (7.5 tons/ ha) followed by LPNBR 1618 (6.3 tons/ ha) in Terai regions (Hardinath and Parwanipur). Similarly, LPNBR1618 gave the highest grain yield (10.3 
tons/ ha) followed by LPNBR1615 (9.5 tons/ ha) in mid hill regions (Kabre, Khumaltar and Lumle).

Table 3: Individual and combined grain yield of Chinese hybrid rice genotypes across five locations (1: Hardinath, 2: Parwanipur, 3: Kabre, 4: Khumaltar, 5: Dhakaltar) and year 2017.

\begin{tabular}{|c|c|c|c|c|c|c|c|c|}
\hline \multicolumn{9}{|c|}{ Grain Yield (tons/ ha) } \\
\hline $\begin{array}{l}\text { Location } \\
\text { Genotypes }\end{array}$ & 1 & 2 & $\begin{array}{l}1-2 \\
\text { Average }\end{array}$ & 3 & 4 & 5 & $\begin{array}{l}\text { 3- } 4-5 \\
\text { Average }\end{array}$ & $\begin{array}{l}\text { Combined } \\
\text { across all } 5 \\
\text { locations }\end{array}$ \\
\hline LPNBR1628 & $5.63^{b}$ & 7.84 & 6.74 & 8.56 & $13.46^{\mathrm{c}}$ & 5.86 & 9.29 & $8.27^{b}$ \\
\hline LPNBR1615 & $5.22^{a}$ & 6.55 & 5.89 & 11.2 & $11.46^{\mathrm{b}}$ & 7.64 & 10.1 & $8.41^{c}$ \\
\hline LPNBR1618 & $5.12^{\mathrm{a}}$ & 6.13 & 5.63 & 10.09 & $10.18^{\mathrm{a}}$ & 7.25 & 9.17 & $7.75^{\mathrm{a}}$ \\
\hline LPNBR1632 & $7.61^{c}$ & 7.17 & 7.39 & 9.7 & $10.17^{\mathrm{a}}$ & 6.38 & 8.75 & $8.21^{\mathrm{b}}$ \\
\hline Grand mean & 5.9 & 6.92 & & 9.89 & 11.32 & 6.78 & & 8.16 \\
\hline $\mathrm{CV}(\%)$ & 6.71 & 8.22 & & 9.34 & 10.32 & 8.75 & & 8.668 \\
\hline LSD (0.05) & 0.6 & 0.87 & & 2.9 & 1.17 & 2.6 & & 1.55 \\
\hline $\mathrm{P}$ value (Gen) & $<0.001$ & NS & & $<0.05$ & $<0.001$ & NS & & NS \\
\hline Env & & & & & & & & $<0.001$ \\
\hline $\mathrm{G} \times \mathrm{E}$ & & & & & & & & $<0.001$ \\
\hline \multicolumn{9}{|c|}{$\begin{array}{l}\text { The same letter superscript within the column denotes the two means have statistically no difference, whereas differer } \\
\text { letter superscripts denote the two means have significant difference. NS: Non-significant difference at } p<0.05 \text { level. }\end{array}$} \\
\hline \multicolumn{9}{|c|}{$\begin{array}{l}\text { Table 4: Individual and combined grain yield of Chinese hybrid rice genotypes across fiv } \\
\text { locations (1: Hardinath, 2: Parwanipur, 3: Kabre, 4: Khumaltar, 5: Dhakaltar) and year } 2018 .\end{array}$} \\
\hline \multicolumn{9}{|c|}{ Grain Yield (tons/ ha) } \\
\hline location & 1 & 2 & $\begin{array}{l}1-2 \\
\text { average }\end{array}$ & 3 & 4 & 5 & $\begin{array}{l}3-4-5 \\
\text { average }\end{array}$ & $\begin{array}{l}\text { Combined } \\
\text { across all } 5 \\
\text { locations }\end{array}$ \\
\hline \multicolumn{9}{|l|}{ Genotypes } \\
\hline LPNBR1628 & $5.77^{b}$ & 7.64 & 6.71 & 9.86 & $12.28^{\mathrm{c}}$ & 5.67 & 9.27 & $8.24^{c}$ \\
\hline LPNBR1615 & $4.02^{\mathrm{a}}$ & 7.29 & 5.66 & 9.4 & $10.17^{b}$ & 5.3 & 8.29 & $7.24^{\mathrm{ab}}$ \\
\hline LPNBR1618 & $5.76^{b}$ & 7.48 & 6.62 & 9.8 & $11.12^{b}$ & 5.29 & 8.74 & $7.89^{b}$ \\
\hline LPNBR1632 & $6.32^{c}$ & 8.04 & 7.18 & 6.7 & $9.7^{\mathrm{a}}$ & 4.83 & 7.08 & $7.12^{\mathrm{a}}$ \\
\hline Grand mean & 5.47 & 7.61 & & 8.94 & 10.82 & 5.27 & & 7.62 \\
\hline $\mathrm{CV}(\%)$ & 6.9 & 5.2 & & 9.1 & 8.5 & 6.2 & & 7.19 \\
\hline $\operatorname{LSD}(0.05)$ & 0.63 & 1.25 & & 3.3 & 1.49 & 4.72 & & 2 \\
\hline$P$ value (Gen) & $<0.001$ & NS & & NS & $<0.001$ & NS & & NS \\
\hline Env & & & & & & & & $<0.001$ \\
\hline $\mathrm{G} \times \mathrm{E}$ & & & & & & & & $<0.001$ \\
\hline
\end{tabular}

The same letter superscript within the column denotes the two means have statistically no difference, whereas different letter superscripts denote the two means have significant difference. NS: Non-significant difference at $p<0.05$ level. 
Table 5: Individual and combined grain yield of Chinese hybrid rice genotypes across five locations (1: Hardinath, 2: Parwanipur, 3: Kabre, 4: Khumaltar, 5: Dhakaltar) and two years (2017 and 2018).

\begin{tabular}{|c|c|c|c|c|c|c|c|c|}
\hline \multicolumn{9}{|c|}{ Grain Yield (t/ha) } \\
\hline location & 1 & 2 & $\begin{array}{l}1-2 \\
\text { Average }\end{array}$ & 3 & 4 & 5 & $\begin{array}{l}3-4-5 \\
\text { Average }\end{array}$ & $\begin{array}{l}\text { Combined } \\
\text { across all } 5 \\
\text { locations }\end{array}$ \\
\hline \multicolumn{9}{|l|}{ Genotypes } \\
\hline LPNBR1628 & $5.30^{\mathrm{b}}$ & 7.04 & 6.2 & 9.2 & $12.77^{\mathrm{b}}$ & 5.52 & 9.2 & $8.25^{b}$ \\
\hline LPNBR1615 & $4.62^{\mathrm{a}}$ & 7.07 & 5.8 & 10.2 & $11.94^{b}$ & 6.47 & 9.5 & $7.82^{a b}$ \\
\hline LPNBR1618 & $5.70^{\mathrm{b}}$ & 6.96 & 6.3 & 12.7 & $11.53^{b}$ & 6.62 & 10.3 & $7.82^{a b}$ \\
\hline LPNBR1632 & $7.46^{\mathrm{c}}$ & 7.6 & 7.5 & 7.7 & $8.92^{\mathrm{a}}$ & 5.66 & 7.4 & $7.66^{\mathrm{a}}$ \\
\hline Grand mean & 5.77 & 7.17 & 6.5 & 10.45 & 11.29 & 6.07 & 9.3 & 7.89 \\
\hline $\mathrm{CV}(\%)$ & 6.8 & 7.9 & & 8.8 & 8.3 & 16.4 & & 10 \\
\hline $\operatorname{LSD}(0.05)$ & 0.61 & 0.87 & & 2.917 & 1.46 & 1.55 & & 1.389 \\
\hline $\mathrm{P}$ value (Gen) & $<0.001$ & NS & & $<0.05$ & $<0.001$ & NS & & NS \\
\hline Env & & & & & & & & $<0.05$ \\
\hline Year & & & & & & & & 0.03 \\
\hline $\mathrm{G} \times \mathrm{E}$ & & & & & & & & $<0.001$ \\
\hline$G \times Y$ & & & & & & & & NS \\
\hline Ex Y & & & & & & & & $<0.05$ \\
\hline Gx Ex Y & & & & & & & & NS \\
\hline
\end{tabular}

The same letter superscript within the column denotes the two means have statistically no difference, whereas different letter superscripts denote the two means have significant difference. NS: Non-significant difference at $p<0.05$ level.

\subsection{Genotype $\times$ environment interaction}

The pooled analysis of variance for grain yield showed that genotypic variation and genotypes and environment interaction were found significant (Table 3, 4, 5). It means that the environment or location factor contributing to differences in mean grain yield across five locations and two years may be due to variation in soil types, sowing date, sunshine hours and amount of rainfall, humidity, and altitude during the crop life cycle. In pooled analysis, genotypes LPNBR1618 (8.25 tons/ ha) and LPNBR1615 and LPNBR1628 (7.82 tons/ ha) produced significantly highest grain yield across five locations and two years in 2017 and 2018 (Table 5). This result revealed that there was a differential yield performance among genotypes across the environments due to the presence of $G \times E$ interaction. The relative contributions of $G \times E$ interaction effects for grain yield in this study were similar to the findings in other studies (Saied 2010, Tariku et al. 2013).

The combined mean square analysis for grain yield indicated the significance differences among the hybrid genotypes across the five locations (Table 5). Therefore, the significant mean square analysis for location revealed that genetic potentials of the genotypes were predisposed by the surroundings owing to the consequence of diversity in the surroundings. 
Table 6. ANOVA results showing level of significance for the genotype $\mathrm{x}$ environment interaction for grain yield at five locations for two years (2017-2018).

\begin{tabular}{lllll}
\hline Sources of variation & df & Sum Square & Mean Square & F Value \\
\hline Gen & 3 & 3.4811 & 1.1604 & 1.86 \\
Env & 4 & 370.664 & 92.666 & $148.34 * * *$ \\
Year & 1 & 3.2041 & 3.2041 & $5.13 *$ \\
Gen $\times$ Env & 12 & 66.6666 & 5.5555 & $8.89 * * *$ \\
Gen $\times$ Year & 3 & 3.2015 & 1.0672 & 1.71 \\
Env $\times$ Year & 3 & 11.5021 & 3.834 & $6.14 * *$ \\
Gen $\times$ Env $\times$ Year & 9 & 6.4312 & 0.7146 & 1.14 \\
Error & 35 & 21.863 & 0.6247 & \\
***Significant at $P<0.001$, **Significant at $P<0.01$, *Significant at $P<0.05$ & &
\end{tabular}

\subsection{Stability analysis}

An ideal genotype gives the highest yield across tested environments and is suitable in its performance. For broad selection, the ideal genotypes are those that have both higher mean yield across test environments and is absolutely stable in performance (Yan and Rajcan 2002, Yan and Kang 2003, Farshadfar et al. 2012). An "ideal" view was drawn (Figure 1) that showed LPNBR1615 was the closest to the ideal genotype. A genotype closer to the "ideal" genotype is more desirable. GGE biplot showed genotype LPNBR1615 was stable genotype under tested environments (Figure 1). Thus, this genotype was recommended for release as a variety to improve rice production in mid hill environments of Nepal. Mean yield performance along with rank of genotypes across environments indicated that the genotypes have high variation around the mean yield. This result is similar to result obtained by Sharifi et al. (2017).

In this research, the portioning of $\mathrm{G} \times \mathrm{E}$ interaction through GGE biplot analysis showed that PC1 and PC2 accounted for $59.57 \%$ and $36.84 \%$ of GGE sum of squares, respectively, and explained $96.41 \%$ of the total variance (Figure 1, Figure 2). The allocation of potential mega-environments is shown by "which won where" graph. The biplot (Figure 2) represents a polygon indicating that the vertex genotypes were LPNBR1618, LPNBR1635, LPNBR1628 and LPNBR1632. The genotypes positioned on the vertexes have the longest distance from the biplot origin, they are supposed to be the most responsive either best or the poorest at one or every environment (Yan and Tinker 2006). The lines perpendicular to the polygon separates the megaenvironments.

The first section contains one genotype LPNBR1632 suggesting the high yielding genotype for Parwanipur and Hardinath locations. The second section contains one genotype LPNBR1628 and LPNBR1615 suggesting the high yielding genotype for Khumaltar location. The fourth section contains one genotype LPNBR1618 suggesting the high yielding genotype for Dhakaltar location. Previously, various stability measurements have been used by Finlay and Wilkinson (1963) that have considered linear regression slopes as a measure of stability. 


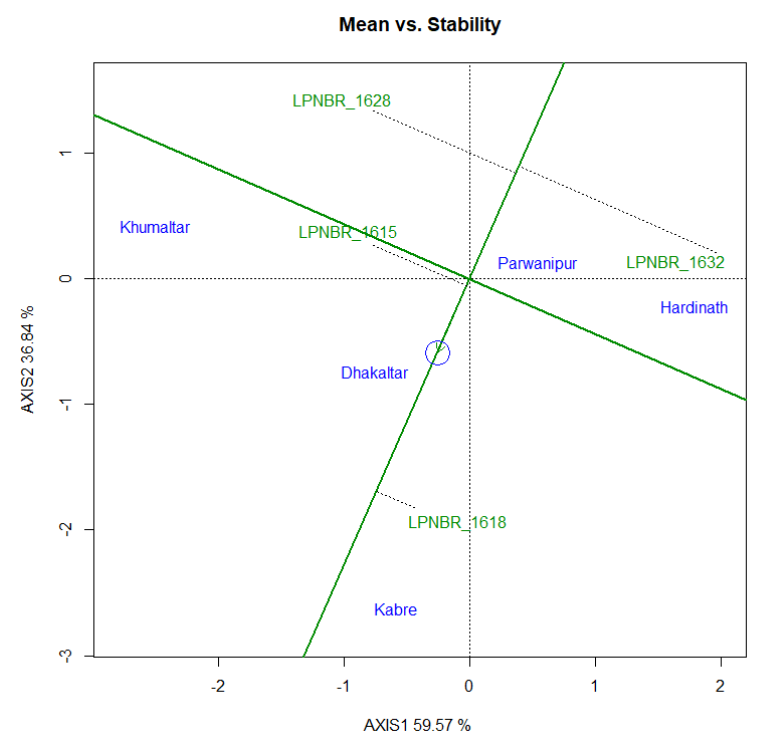

Fig. 1. GGE biplot showing ranking of Chinese hybrid rice varieties for mean yield and stability

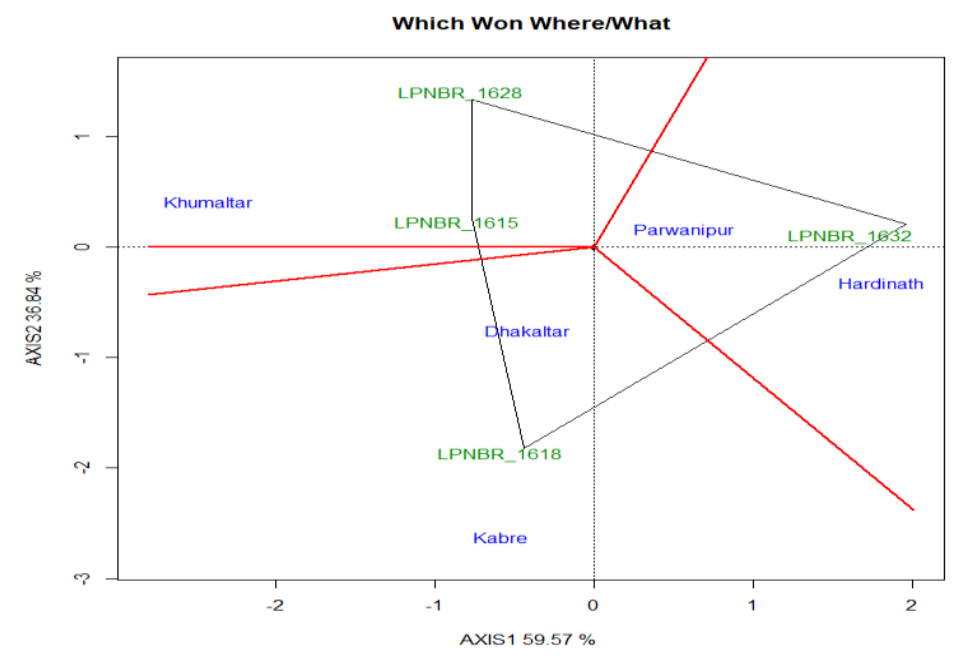

Fig. 2. Polygon view of GGE biplot to the identification winning of Chinese hybrid rice varieties and their related mega environments

Eberhart and Russel (1966) stressed the need to consider both linear and nonlinear components in $\mathrm{G} x$ E interaction in evaluating the stability of the genotypes. According to this model, the term stable variety has been used for a variety that performs 
uniformly in all environments. Hence, the stable variety has high mean (Xi), unit regression ( $\mathrm{bi}=1.0)$ and the deviations from regression as small as possible $\left(\mathrm{S}^{2} \mathrm{di}=0\right)$. The coefficient of regression (bi) explains the adaptiveness of the tested genotypes over the evaluated environments. The varieties with b-value near to unity and higher mean grain yield show the more average stability. Genotypes with high mean, bi>1 with non-significant $S^{2}$ di are considered as below average in stability. Such genotypes tend to respond favourably to better environments but give poor yield in unfavourable environments. Hence, they are suitable for favourable environments. Genotypes with low mean, bi<1 with non-significant $S^{2}$ di do not respond favourably to improved environmental conditions and hence, it could be regarded as specifically adapted to poor environments (Eberhart and Russell 1966). Genotypes with high mean, bi>1 with non-significant $S^{2}$ di are considered as below average in stability. Such genotypes tend to respond favourably to better environments but give poor yield in unfavourable environments. Hence, they are suitable for favourable environments (Eberhart and Russell, 1966). The Table 7 showed that the genotypes namely LPNBR1615 ( $b=1.13)$, LPNBR1618 $(b=1.19)$ and LPNBR1628 $(b=1.15)$ had more than unity regression indicating the genotype's suitability towards favorable environments (Khumaltar and similar environments).

Table 7. Mean grain yield values (t/ha) and stability parameters for 4 Chinese hybrid rice genotypes across 5 environments

\begin{tabular}{lllll}
\hline Genotype & $\mathrm{Sd}$ & $\mathrm{bi}$ & $\mathrm{S}^{2} \mathrm{di}$ & $\mathrm{R}^{2}$ \\
\hline LPNBR1615 & 2.957 & 1.1325 & 0.1958 & 0.9574 \\
LPNBR1618 & 3.175 & 1.1966 & 0.6791 & 0.9271 \\
LPNBR1628 & 3.1058 & 1.1598 & 0.8531 & 0.9103 \\
LPNBR1632 & 1.5485 & 0.5112 & 0.622 & 0.7113 \\
\hline
\end{tabular}

$b i=$ regression coefficient,$S d=$ Standard deviation, $S^{2} d i=$ the deviations from regression,

$R^{2}=$ coefficient of determination. (Eberhart and Russell 1966).

\section{Conclusions}

The present study provided an evaluation of genotypic and environmental performance of Chinese hybrid varieties under different environments. Significant differences among the hybrid rice genotypes within environments for yield trait suggested the presence of wide variability. Based on results, rice genotypes namely LPNBR1615, LPNBR1618 and LPNBR1628 gave higher grain yield and showed adaptability under favorable environments. The yield stability across different environments varied among Chinese hybrid rice genotypes. The stability analysis showed that the genotype LPNBR1615 was higher yielder and the more stable genotype to favorable environments. This study suggests that farmers can grow this genotype for higher production in Khumaltar, Lalitpur, Nepal and similar environments. 


\section{Acknowledgements}

This research was supported by Nepal Agricultural Research Council. Technical assistance in field experiments from field staffs of Hill Crops Research Program, Kabre, Dolakha, Regional Agricultural Research Station, Lumle, Kaski,Agriculture Botany Division, Khumaltar, Lalitpur, National Rice Research Program, Hardinath, Dhanusha,Regional Agricultural Research Station, Parwanipur, Bara are acknowledged. Comments on the initial draft from two anonymous RJS reviewers are acknowledged.

\section{References}

Acuna TLB, Lafitte HR, Wade LJ. 2008. Genotype and environment interactions for grain yield of upland rice backcross lines in diverse hydrological environments. Field Crops Research 108: 117-125.

Blanche SB, Utomo HS, Wenefrida I, Myers GO. 2009. Genotype $\times$ environment interactions of hybrid and varietal rice cultivars for grain yield and milling quality. Crop Science 49: 2011-2018.

Bhurer KP, Yadav DN, Ladha JK, Thapa RB, Pandey KR. 2013. Efficacy of various herbicides to control weeds in dry direct seeded rice (Oryza sativa L.). Global Journal of Biology: Agriculture and Health Sciences 2(4): 205-212.

CBS. 2018. National Population and Housing Census. Government of Nepal, National Planning Commission Secretariat, Central Bureau of Statistics (CBS), Kathmandu, Nepal.

Eberhart SA, Russell WA. 1966. Stability parameters for comparing varieties. Crop Science 6 (1): 36-40.

Farshadfar E, Mohammadi R, Aghaee M, Vaisi Z. 2012. GGE biplot analysis of genotype $\times$ environment interaction in wheat-barley disomic addition lines. Australian Journal of Crop Science 6(6): 10471079.

Finlay KW, Wilkinson GN. 1963. The analysis of adaptation in a plant breeding programme. Australian Journal of Agricultural Research 14: 742-754.

Gomez KA, Gomez AA. 1984. Statistical Procedures for Agricultural Research. $2^{\text {nd }}$ ed. John Wiley and Sons, NY, U.S.A.

Huang M, Tang Q, AO H, Zou Y. 2017. Yield potential and stability in super hybrid rice and its production strategies. Journal of Integrative Agriculture 16 (5): 1009-1017.

IRRI. 2019. Hybrid rice. Retrieved July 4, 2019, from https://www.irri.org/hybrid-rice

Khadka D, Lamichhane S, Bhurer K, Chaudhary J, Ali M, Lakhe L. 2018. Soil fertility assessment and mapping of regional agricultural research station, Parwanipur, Bara, Nepal. Journal of Nepal Agricultural Research Council 4(1): 33-47.

Messina C, Hammer G, Dong Z, Podlich D, Cooper M. 2009. Modelling crop improvement in a G×ExM framework via gene-trait-phenotype relationships. In: Sadras VO, Calderini D (Eds.) Crop physiology: Applications for Genetic Improvement and Agronomy. Elsevier, Netherlands, 235-265 p.

NARC. 2018 a. Annual Report (2017/18) of Nepal Agricultural Research Council (NARC), National Rice Research Program, Hardinath, Dhanusha, Nepal.

NARC. 2018 b. Annual Report (2017/18) of Nepal Agricultural Research Council (NARC), Hill Crops Research Program, Kabre, Dolakha, Nepal.

NARC. 2018 c. Annual Report (2017/18) of Nepal Agricultural Research Council (NARC), Agronomy Botany Division, Khumaltar, Lalitpur, Nepal.

NARC. 2018 d. Annual Report (2017/18) of Nepal Agricultural Research Council (NARC), Regional Agricultural Research Station, Lumle, Kaski, Nepal.

NARC. 2018 e. Annual Report (2017/18) of Nepal Agricultural Research Council (NARC), Regional Agricultural Research Station, Parwanipur, Bara, Nepal.

Pacheco A, Vargas M, Alvarado G, Rodríguez F, López M, Crossa J, Burgueño J. 2015. User's Manual GEA-R (Genotype by Environment Analysis with R). "GEA-R (Genotype x Environment Analysis with R for Windows) Version 4.1", hdl:11529/10203, CIMMYT Research Data and Software Repository Network, V16. 
Paranthaman R, Alagusundaram K, Indhumathi J. 2009. Production of Protease from Rice Mill Wastes by Aspergillus niger in Solid State Fermentation. World Journal of Agricultural Sciences 5: 308-312.

Paudel, M.N. 1995. Nutrient management for Sulphan buri-900 rice variety in acid sulfate soil with green leaf manure. M.Sc. Thesis, Asian Institute of Technology, Bangkok, Thailand. Pp 23-51.

Payne R, Murray DA, Harding SA, Baird DB, Soutar DM. 2009. Genstat for Windows (12 ${ }^{\text {th }}$ Edition) Introduction, VSN International, Hemel Hempstead, UK.

Ricepedia. (2020). Rice as food. http://ricepedia.org/rice-as-food

Saied ZF. 2010. Survey of adaptation of thirty rice (Oryza sativa L.) genotypes to west Guilan climatic conditions-Astara. Journal of Crop Ecophysiology 4(15): 111-126.

Samonte SOP, Wilson LT, McClung AM, Medley JC. 2005. Targeting cultivars onto rice growing environments using AMMI and SREG GGE biplot analyses. Crop Science 45: 2414-2424.

Sharifi P, Aminpanah H, Erfani R, Mohaddesi A, Abbasian A. 2017. Evaluation of Genotype $\times$ Environment Interaction in Rice Based on AMMI Model in Iran. Rice Science 24(3):173-180.

Tariku S, Lakew T, Bitew M, Asfaw M. 2013. Genotype by environment interaction and grain yield stability analysis of rice (Oryza sativa L.) genotypes evaluated in north western Ethiopia. Net Journal of Agricultural Science 1(1): 10-16.

Tripathi BP, Bhandari HN, Ladha, JK. 2019. Rice Strategy for Nepal. Acta Scientific Agriculture 3(2): 171-180.

USDA. 2020. Rice Sector at a Glance. https://www.ers.usda.gov/topics/crops/rice/rice-sector-at-aglancel

Virmani SS. 2003. Advances in hybrid rice research and development in the tropics: Hybrid rice for food security, poverty alleviation and environmental protection. Proceedings of the $4^{\text {th }}$ International Symposium on Hybrid Rice, May 14-17, 2003, International Rice Research Institute, Hanoi, Vietnam Los Banos Philippines, pp: 2-20.

Wade LJ, McLaren CG, Quintana L, Harnpichitvitaya D, Rajatasereekul S. 1999. Genotype by environment interactions across diverse rainfed lowland rice environments. Field Crops Research 64: 35-50.

Yan W, Rajcan I. 2002. Biplot analysis of test sites and trait relations of soybean in Ontario. Crop Science 42: 11-20

Yan W, Tinker NA. 2006. Biplot analysis of multi-environment trial data: Principles and applications. Canadian Journal of Plant Science 86: 623-645.

Yan W, Kang M S. 2003. GGE biplot analysis: a graphical tool for breeders, Geneticists and Agronomists.

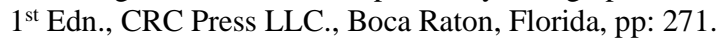

